\title{
Validity and reliability of a Persian version of a questionnaire on knowledge of health care providers about sexually transmitted infections
}

D. Pourmarzi ${ }^{1}$, S. Taromian ${ }^{2}$, M. Razi ${ }^{3}$, A. Esmaeili-Hesari ${ }^{4}$

$$
\begin{aligned}
& \text { مصدوقية وموثوقية إحدى النسخ الفارسية لاستبيان عن معلومات مقدمي الرعاية الصحية المتعلقة بالأمر اض المُعدية المنقولة جنسياً }
\end{aligned}
$$

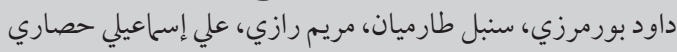

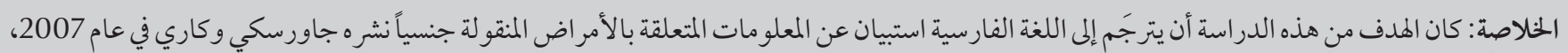

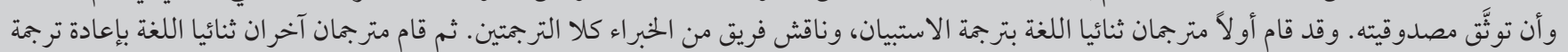

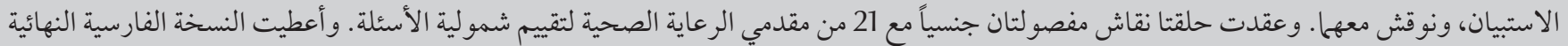

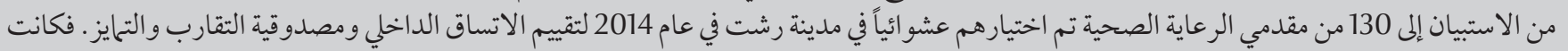

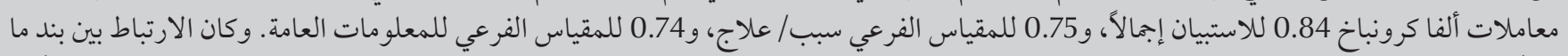

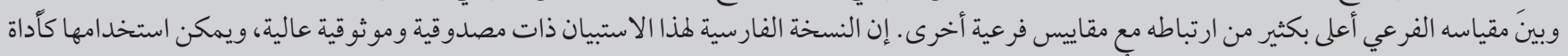

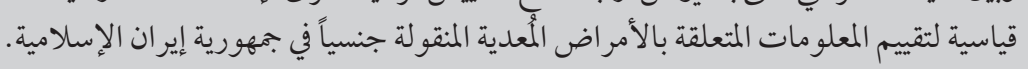

ABSTRACT The aim of this study was to translate into Persian and validate a questionnaire on knowledge about sexually transmitted diseases published by Jaworski and Carey in 2007. The questionnaire was forward-translated by two bilingual translators, and both translations were discussed by an expert team. The questionnaire was then back-translated by two other bilingual translators and discussed with both of them. Two sex-segregated focus group discussions were held with 21 health care providers to evaluate the comprehensibility of the questions. The final Persian version of the questionnaire was administered to 130 randomly selected health care providers in Rasht in 2014 to assess internal consistency and convergent and discriminant validity. The Cronbach's alpha coefficients were 0.84 for the overall questionnaire, 0.75 for the cause/cure subscale and 0.74 for the general knowledge subscale. The correlation between an item and its subscale was significantly higher than its correlation with other subscales. The Persian version of the questionnaire is highly valid and reliable and can be used as a standard instrument for evaluating knowledge about sexually transmitted infections in the Islamic Republic of Iran.

Validité et fiabilité de la version perse d'un questionnaire sur les connaissances des dispensateurs de soins de santé en matière d'infections sexuellement transmissibles

RÉSUMÉ La présente étude avait pour objectif de traduire en langue perse un questionnaire sur les connaissances en matière d'infections sexuellement transmissibles publié par Jaworski and Carey en 2007 et de procéder à sa validation. Le questionnaire a été traduit vers la langue cible (perse) par deux traducteurs bilingues, et leurs traductions respectives ont été discutées par une équipe d'experts. Le questionnaire a ensuite fait l'objet d'une rétro-traduction dans la langue source (anglais) par deux autres traducteurs bilingues et a été discuté avec ceux-ci. Deux groupes de discussion thématiques non-mixtes réunissant 21 dispensateurs de soins de santé ont été organisés afin d'évaluer l'intelligibilité des questions. La version en langue perse finale du questionnaire a été administrée à 130 dispensateurs de soins de santé sélectionnés de façon aléatoire à Rasht en 2014 dans le but d'évaluer la cohérence interne ainsi que la validité convergente et discriminante. Les coefficients alpha de Cronbach étaient de 0,84 pour le questionnaire dans son ensemble, de 0,75 pour la sous-échelle cause/guérison et de 0,74 pour la sous-échelle de connaissance générale. La corrélation entre un item et sa sous-échelle était significativement plus élevée que sa corrélation avec d'autres sous-échelles. La version du questionnaire en langue perse est parfaitement valable et fiable et peut être utilisée comme instrument normalisé pour l'évaluation des connaissances en matière d'infections sexuellement transmissibles en République islamique d'Iran. 


\section{Introduction}

Sexually transmitted infections (STIs) are prevalent worldwide and are among the top five diseases for which adults seek health care. Every day, more than 1 million people worldwide become infected with one of these diseases (1). The high prevalence and incidence of STIs as well as delays in diagnosis and poor treatment options result in many STI-related complications in developing countries (2). Unfortunately, there are no valid statistics on the prevalence and incidence of STIs in the Islamic Republic of Iran, but the estimated incidence of infection with Neisseria gonorrhoeae, Chlamydia trachoma and syphilis per 1000 women was 2.44, 5.02 and 0.04 , respectively; the corresponding figures per 1000 men were $0.43,0.82$ and 0.005 (3).

Because of strong taboos and negative stigma related to STIs, lack of information about sexual health and the asymptomatic nature of many STIs, few people seek medical treatment for them (3). Furthermore, many health systems do not have effective STI control and prevention programmes, and the health services provide inadequate care for STIs (4).

Health care providers have an undeniable role in reducing the burden of STIs. For a health system to be effective in controlling and preventing STIs, health care providers must have sufficient knowledge about these infections. Therefore, well-designed educational programmes are necessary (5). Evaluation of health care providers' knowledge and of their educational needs is an important stage in designing STI educational programmes and in evaluating their efficacy (6). A standard instrument for such evaluations makes it possible to identify strengths and weaknesses (7); however, developing a standard instrument is both difficult and time-consuming, and use of existing instruments is common. Standard instruments are usually translated and sometimes adapted culturally (8). The comparability of research results derived with the same instrument in different cultures is important (9).

There is no standard questionnaire for evaluating knowledge about STIs in Persian. Questionnaires are available only to evaluate knowledge about HIV/AIDS (10) and hepatitis B (11). We therefore translated into Persian and validated a standard instrument for evaluating the knowledge of health care providers about STIs. Although it is important to have comprehensive information about the process of translation and its validity in order to assess the adequacy of a translation, most validations of translations emphasize psychometric testing rather than other aspects of validity (12). In this article, we describe all the steps in making a valid translation of a standard questionnaire.

\section{Materials and methods}

We translated and validated the Sexually Transmitted Disease Knowledge Questionnaire, a standard, brief but comprehensive instrument developed by Jaworski and Carey in 2007 (13). We translated two main sections of the instrument: cause/cure and general knowledge about STIs. The cause/cure section contains 9 items, and the general knowledge section has 12 items. We added six supplementary public health items, resulting in a 27 -item questionnaire. Each item has three response options: true, false, do not know. The score for each correct answer was 1 , and the incorrect answer or don't know was scored as 0 . The total score ranged from 0 to 27. Jaworski and Carey found that the internal consistency of the instrument (Cronbach's alpha $=0.86$ ) and test-retest reliability (0.88) were excellent (13).

The questionnaire was translated in four stages: forward-translation, discussion with experts, back-translation and comprehensibility of the questionnaire (14) (Figure 1).

Forward translation: In the first stage, two bilingual translators (Persian-English) who were native speakers of Persian independently produced two initial Persian versions.

Discussion with experts: These two versions were discussed for about 1.5 $h$ by an expert team consisting of three general physicians, two epidemiologists, one midwife, one nurse and one infectious disease specialist. The team chose the most appropriate words for the initial forward-translation, provided suggestions for improving the translated questionnaire and produced an initial Persian version.

Back-translation: The initial Persian version was back-translated into English by two bilingual translators, one native English-speaker and one native Persianspeaker. The English-speaker had been living in the country for about 6 years, and the Persian-speaker had lived in the USA for about 4 years. The translators had not seen the original questionnaire. The back-translated version was compared with the original English version, and any discrepancy or variation between them was resolved by discussion between the principal researcher and the two back-translators (15). Some changes were made to the Persian version on the basis of the discussions.

Comprehensibility of the questionnaire: Two focus group discussions were held to ensure a readily understandable questionnaire. The final Persian questionnaire was administered to 21 health care providers in two groups consisting of 10 men and 11 women to evaluate the comprehensibility and wording. The participants were asked to rate the clarity and simplicity of the words and sentences on a three-point Likert scale ( 1 = very simple or very clear, $2=$ simple or clear, 3 = difficult or unclear). Words or sentences given a rating of 3 by even one of participants were discussed to change the problematic parts (16). 


\section{Psychometric testing}

The validity and reliability of the final Persian version of the questionnaire were assessed in a cross-sectional study involving 130 health care providers working at health centres in Rasht in the northern part of the country between September and October 2014. Rasht, the capital of Guilan Province, has 41 rural and urban health centres that provide primary health care for about 1 million inhabitants. We included only the 190 health care providers who had worked for at least 1 year in family health, disease control and prevention or as midwives and had thus been involved in STI control and prevention programmes. Random sampling was conducted based on the employee number of the health expert. Of the 137 health experts selected, 130 agreed to participate in the study. We chose five candidates for each of the 26 items, for a total of 130 participants (17).

The study participants gave informed consent to participate in the study and then received the Persian version of the questionnaire. We collected some demographic data on the participants: age, gender, educational degree, university qualification, job title, years since graduation and work experience. The participants filled out the questionnaires and submitted them in sealed envelopes.

\section{Internal consistency}

The reliability of a measure is its consistency or repeatability (18). To test the reliability of the questionnaire, we analysed internal consistency by computing Cronbach's alpha coefficient, which shows how closely related a set of items are as a group (19). Coefficients > 0.70 were accepted.

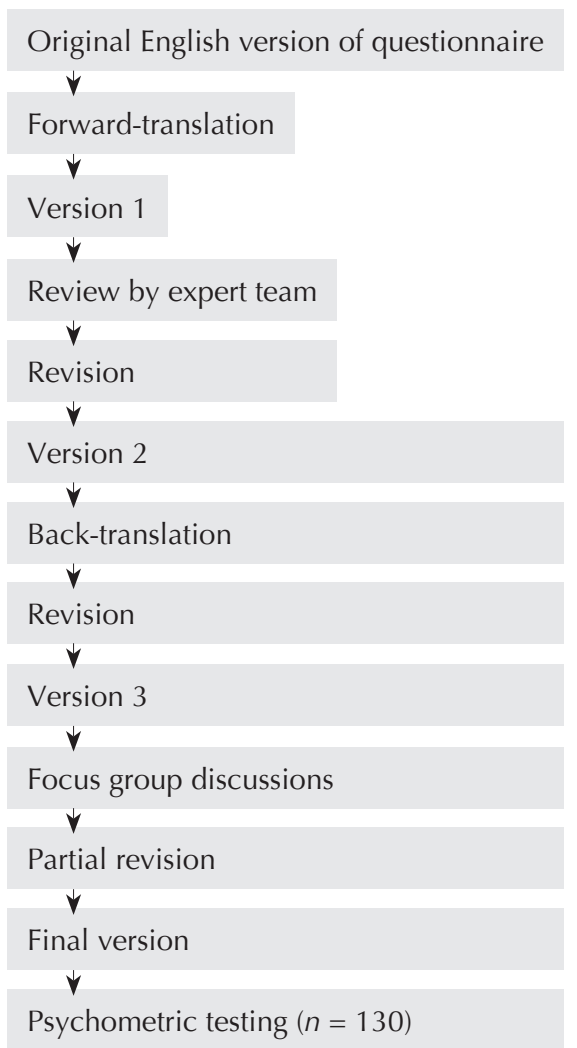

\section{Convergent and discriminant validity}

Validity indicates that a questionnaire measures what it is meant to measure. Convergent validity is a measure of whether constructs that are theoretically related are in fact related. Discriminant (or divergent) validity is a measure of whether constructs that should not be related are in fact not related (18).

Pearson's correlation coefficient was used to test the correlation between questionnaire scales and items. The level of measurement was continuous, and linearity, normality and homoscedasticity were tested to meet the correlation assumptions. Correlation coefficients were computed for each item with its own scale and with another scale. Scales and items with a correlation coefficient $>0.4$ were considered highly correlated. An item for which 
the correlation with its own scale was greater than the correlation with the other scale was considered to have succeeded the test of discriminant validity. IBM SPSS software version 21 was used for statistical analyses.

\section{Ethical considerations}

The protocol of the study was approved by the ethical committee of Guilan University of Medical Sciences. Participants provided written informed consent; participation in the study was voluntary, and all the questionnaires were anonymous.

\section{Results}

\section{Translation}

Forward-translation: A question in the original version about use of natural skin condoms was removed because this type of condom does not exist in the country, and people are not familiar with it. Hence, the Persian version of the questionnaire contains only 26 items. The two translations were similar, although with some wording differences. For example "by" in questions 1 and 5 was translated as bevasileie by one translator and aztarigheh by the other.

Expert panel: The expert panel accepted the translations of questions 3 , $4,6,8,9,13,15,18,22$ and 26 with no changes. The principal investigator modified other questions on the basis of the experts' suggestions. Most of those revisions were minor. For example, "genital herpes" was translated as "Herpestanasoli", while the experts suggested "Tabkhaletanasoli" in questions 1 and 20; "sexually transmitted infection" was translated as bimarihaye montaghele az rah jensi, which was changed to bimarihaye mogharebati, with darnahietanasoli (in the genital area) in question 20; and translations of "penis or vagina" in question 7 were removed.

Back-translation: The two translators provided similar translations for 21 questions, with discrepancies in a few

\begin{tabular}{|c|c|}
\hline Variable & No. (\%) \\
\hline \multicolumn{2}{|l|}{ Age group (years) } \\
\hline $25-35$ & $38(30.4)$ \\
\hline $36-45$ & $65(52.0)$ \\
\hline 46-55 & $22(17.6)$ \\
\hline \multicolumn{2}{|l|}{ Gender } \\
\hline Male & $28(21.5)$ \\
\hline Female & $102(78.5)$ \\
\hline \multicolumn{2}{|l|}{ Degree } \\
\hline Associate & $81(62.3)$ \\
\hline Bachelor & $49(37.7)$ \\
\hline \multicolumn{2}{|l|}{ University qualification } \\
\hline Public health & $59(45.4)$ \\
\hline Midwifery & $71(54.6)$ \\
\hline \multicolumn{2}{|l|}{ Job title } \\
\hline Midwife & $38(29.3)$ \\
\hline Family health expert & $61(46.9)$ \\
\hline Disease prevention and control expert & $31(23.8)$ \\
\hline \multicolumn{2}{|l|}{ Time since graduation (years) } \\
\hline$\leq 5$ & $9(7.2)$ \\
\hline $6-10$ & $25(20.0)$ \\
\hline $11-14$ & $33(26.4)$ \\
\hline$\geq 15$ & $58(46.4)$ \\
\hline \multicolumn{2}{|l|}{ Work experience (years) } \\
\hline$\leq 5$ & $9(7.0)$ \\
\hline $6-10$ & $38(29.5)$ \\
\hline $11-14$ & $14(10.8)$ \\
\hline$\geq 15$ & $68(52.7)$ \\
\hline
\end{tabular}

words for the other five. After comparison of the two back-translated questionnaires with the original, discrepancies were detected in questions $3,4,5,7$, $8,10,17$ and 20 . The original version and two back-translated versions of the questionnaires were given to both back-translators for comparison. The translators approved 18 questions with no changes and suggested some modifications of the Persian version for others. For example, darmanghatee instead of darman for "cure" in questions 3 and 8, alodeh mishavand instead of mobtala mishavand for "to get" in question 4, and vaziyatebimari instead of chegonegibimari for "how sick" in question 17. The principal researcher edited some words on the basis of the suggestions of the two back-translators.

Focus group discussion: The focus group sessions lasted about $35 \mathrm{~min}$ with the men and about $50 \mathrm{~min}$ with the women. All members of the groups emphasized the importance of putting sentences into a table. The groups found that questions 9, 10, 13, 19 and 22 were unclear or complicated and provided suggestions for revising them. After discussion, the back-translators made some modifications, such as darheynezayeman instead of darteyeporoseyezayeman for "during childbirth" in question 9 and mitavanadmotavajeh shaved instead of mitavanadbegoyadke for "can tell" in questions 19 and 22. The revised questionnaire was given to some focus 


\begin{tabular}{|c|c|c|c|}
\hline Scale & Item & Cause/cure & $\begin{array}{c}\text { General } \\
\text { knowledge }\end{array}$ \\
\hline \multirow[t]{9}{*}{ Cause/cure factor } & Genital herpes is caused by HIV. & 0.560 & 0.328 \\
\hline & Frequent urinary infections can lead to Chlamydia infection. & 0.569 & 0.203 \\
\hline & Gonorrhoea can be cured. & 0.429 & 0.234 \\
\hline & Human papillomavirus (HPV) is the same virus as HIV. & 0.718 & 0.368 \\
\hline & Chlamydia infection can be cured. & 0.562 & 0.338 \\
\hline & The same virus causes all sexually transmitted diseases. & 0.441 & 0.303 \\
\hline & Human papillomavirus (HPV) can cause genital warts. & 0.616 & 0.264 \\
\hline & Human papillomavirus (HPV) can lead to cancer in women. & 0.587 & 0.330 \\
\hline & Human papillomavirus (HPV) can cause HIV infection. & 0.725 & 0.349 \\
\hline \multirow[t]{12}{*}{ General knowledge } & $\begin{array}{l}\text { Sores develop on the penis or vagina soon after infection with } \\
\text { HIV. }\end{array}$ & 0.314 & 0.474 \\
\hline & $\begin{array}{l}\text { A woman who has genital herpes can pass the infection to her } \\
\text { baby during childbirth. }\end{array}$ & 0.228 & 0.586 \\
\hline & A man must have vaginal sex to get genital warts. & 0.131 & 0.414 \\
\hline & $\begin{array}{l}\text { Sexually transmitted infections can lead to health problems, } \\
\text { which are usually more serious for men than for women. }\end{array}$ & 0.190 & 0.420 \\
\hline & $\begin{array}{l}\text { A woman can tell that she has been infected with Chlamydia if } \\
\text { her vagina has a bad odour. }\end{array}$ & 0.207 & 0.507 \\
\hline & $\begin{array}{l}\text { If a person tests positive for HIV, the test also indicates how sick } \\
\text { the person will become. }\end{array}$ & 0.165 & 0.447 \\
\hline & There is a vaccine for preventing gonorrhoea. & 0.233 & 0.484 \\
\hline & $\begin{array}{l}\text { A woman can tell if she has a sexually transmitted infection from } \\
\text { the way her body feels. }\end{array}$ & 0.379 & 0.714 \\
\hline & There is a vaccine for preventing Chlamydia infection. & 0.387 & 0.564 \\
\hline & A man can tell if he has hepatitis B from the way his body feels. & 0.353 & 0.609 \\
\hline & $\begin{array}{l}\text { A person who had gonorrhoea in the past is immune (protected) } \\
\text { from getting it again. }\end{array}$ & 0.375 & 0.483 \\
\hline & $\begin{array}{l}\text { A man can protect himself from getting genital warts by washing } \\
\text { his genitals after sex. }\end{array}$ & 0.318 & 0.510 \\
\hline
\end{tabular}

groups members to check the suggested changes and was approved.

\section{Psychometric testing}

Basic characteristics of respondents: The mean age of the participants was 39.58 \pm 6.04 years, and most were women (78.5\%), aged $36-45$ years and had an associate degree (62.3\%). For $54.6 \%$, the university qualification was midwifery, and the job title of $46.9 \%$ of participants was family health expert. A high percentage of participants had $\geq$ 15 years of work experience after graduation (Table 1).
Internal consistency: Cronbach's alpha was 0.84 for the overall questionnaire, 0.75 for the cause/cure subscale and 0.74 for general knowledge.

Convergent and discriminant validity: The correlation between an item and its own subscale was significantly higher than its correlation with the other subscale. The correlation between items and their hypothesized subscales was $>0.4$ for all items, which thus passed the test of internal consistency. On the cause/cure subscale, the minimum coefficient was 0.43 for item 3 and the maximum was 0.73 for item 24; on the general knowledge subscale, the coefficients were 0.41 for item 14 and 0.71 for item 19 . As the correlation between an item and the subscale other than its hypothesized subscale was lower than the correlation between that item and its hypothesized subscale, all items passed the test for convergent and discriminant validity (Table 2). Participants' responses to the questionnaire are presented in Table 3.

\section{Discussion}

We found that use of a focus group of experts in health and medicine to 


\begin{tabular}{|c|c|c|c|}
\hline \multirow[t]{2}{*}{ Item } & \multicolumn{3}{|c|}{ Response } \\
\hline & Correct N (\%) & Incorrect N (\%) & $\begin{array}{l}\text { Don't known } \\
\quad \mathrm{N}(\%)\end{array}$ \\
\hline 1. Genital herpes is caused by HIV. & $105(80.8)$ & $6(4.6)$ & $19(14.6)$ \\
\hline 2. Frequent urinary infections can lead to Chlamydia infection. & $45(34.6)$ & $44(33.8)$ & $41(31.5)$ \\
\hline 3. Gonorrhoea can be cured. & $83(63.8)$ & $22(16.9)$ & $25(19.2)$ \\
\hline $\begin{array}{l}\text { 4. A person infected with HIV is more likely to have another sexually } \\
\text { transmitted infection. }\end{array}$ & $95(73.1)$ & $24(18.5)$ & $11(8.5)$ \\
\hline 5. Human papillomavirus (HPV) is the same virus as HIV. & $82(63.1)$ & $10(7.7)$ & $38(29.2)$ \\
\hline 6. Anal sex increases the risk for hepatitis B. & $68(52.3)$ & $35(26.9)$ & $27(20.8)$ \\
\hline $\begin{array}{l}\text { 7. Soon after infection with HIV, a person develops open sores on his or her } \\
\text { genitals (penis or vagina). }\end{array}$ & $106(81.5)$ & $6(4.6)$ & $18(13.9)$ \\
\hline 8. Chlamydia infection can be cured. & $95(73.1)$ & $5(3.8)$ & $30(23.1)$ \\
\hline $\begin{array}{l}\text { 9. A woman who has genital herpes can pass the infection to her baby during } \\
\text { childbirth. }\end{array}$ & $101(77.7)$ & $5(3.8)$ & $24(18.5)$ \\
\hline 10. A woman can tell if she has gonorrhoea by looking at her body. & $88(67.7)$ & $13(10.0)$ & $29(22.3)$ \\
\hline 11. The same virus causes all sexually transmitted infections. & $109(83.8)$ & $15(11.5)$ & $6(4.6)$ \\
\hline 12. Human papillomavirus (HPV) can cause genital warts. & $83(63.8)$ & $4(3.1)$ & $43(33.1)$ \\
\hline 13. Human papillomavirus (HPV) infection can lead to cancer in women. & $72(55.4)$ & $11(8.5)$ & $47(36.2)$ \\
\hline 14. A man must have vaginal sex to get genital warts. & $28(21.5)$ & $69(53.1)$ & $33(25.4)$ \\
\hline $\begin{array}{l}\text { 15. Sexually transmitted infections can lead to health problems, which are } \\
\text { usually more serious for men than for women. }\end{array}$ & $83(63.8)$ & $26(20.0)$ & $21(16.2)$ \\
\hline $\begin{array}{l}\text { 16. A woman can tell that she has been infected with Chlamydia if her vagina } \\
\text { has a bad odour. }\end{array}$ & $64(49.2)$ & $42(32.3)$ & $24(18.5)$ \\
\hline $\begin{array}{l}\text { 17. If a person tests positive for HIV, the test also indicates how sick the person } \\
\text { will become. }\end{array}$ & $55(42.3)$ & $54(41.5)$ & $21(16.2)$ \\
\hline 18. There is a vaccine for preventing gonorrhoea. & $96(73.8)$ & $9(6.9)$ & $25(19.2)$ \\
\hline $\begin{array}{l}\text { 19. A woman can tell if she has a sexually transmitted infection from the way } \\
\text { her body feels. }\end{array}$ & $93(71.5)$ & $15(11.5)$ & $22(16.9)$ \\
\hline $\begin{array}{l}\text { 20. A person who has genital herpes must have open sores to infect his or her } \\
\text { sexual partner. }\end{array}$ & $63(48.5)$ & $39(30.0)$ & $28(21.5)$ \\
\hline 21. There is a vaccine for preventing Chlamydia infection. & $100(76.9)$ & $2(1.5)$ & $28(21.5)$ \\
\hline 22. A man can tell if he has hepatitis B from the way his body feels. & $116(89.2)$ & $4(3.1)$ & $10(7.7)$ \\
\hline $\begin{array}{l}\text { 23. A person who had gonorrhoea in the past is immune (protected) from } \\
\text { getting it again. }\end{array}$ & $98(75.4)$ & $6(4.6)$ & $26(20.0)$ \\
\hline 24. Human papillomavirus (HPV) can cause HIV infection. & $79(60.8)$ & $15(11.5)$ & $36(27.7)$ \\
\hline $\begin{array}{l}\text { 25. A man can protect himself from getting genital warts by washing his } \\
\text { genitals after sex. }\end{array}$ & $84(64.6)$ & $21(16.2)$ & $25(19.2)$ \\
\hline 26. There is a vaccine for preventing hepatitis $B$. & $130(100)$ & 0 & 0 \\
\hline
\end{tabular}

discuss and approve the Persian version before back-translation is important. This also reduces the time required and any confusion after back-translation (20).

Any difficulty in understanding the translated version by the study participants led to modification of the questionnaire according to their suggestions. Assessing the comprehensibility of an instrument, especially one that is selfadministered, is an important phase, and the focus group discussion with the target group ensured an understandable scale $(8,9)$. In this study, the focus groups were conducted in sex-segregated environments, because the instrument addresses sexual issues, which are considered shameful in Iranian culture, even in a health setting. Holding sex-segregated sessions can therefore encourage focus group members to engage in discussions and express their views (21). The viewpoints of both the target groups and the experts are necessary for a proper version of a questionnaire in the target language.

The psychometric aspects of our study proved the utility of the translated questionnaire. To assess the internal 
reliability and validity of the questionnaire, we analysed data from 130 health care providers, which showed that the Persian version is both reliable and valid. We did not, however, assess test-retest reliability, which is recommended for assessing a questionnaire.

An important strength of our study is use of a multi-method approach to translating the questionnaire, which can reduce a source of method bias in translation and adaptation of a questionnaire (8). In the forward-translation step, we found only minor wording differences between the versions of the two qualified translators, who produced their translations independently, which ensures the best translation (14).
One limitation of this study is that it was conducted with health care providers, and the reliability of the scale for another sample group should be assessed.

\section{Conclusion}

Our analyses confirm that the Persian version of the questionnaire on knowledge about STIs is reliable, and the scale items have high internal consistency. The validity of the instrument was proved by convergent and discriminant validity assessment. The Persian version of the questionnaire is a brief, internally consistent and valid. It can be used to assess the knowledge of health care providers about STIs and the efficacy of STI educational programmes and risk reduction programmes.

\section{Acknowledgements}

The authors thank the Vice Chancellor for Research of Guilan University of Medical Sciences for funding this project and for kind collaboration. They are also grateful to the Rasht health centres for their participation. They also thank all the participants for their collaboration.

\section{Funding: None.}

Competing interests: None declared.

\section{References}

1. Sexually transmitted infections (STIs) (Fact sheet No. 110). Geneva: World Health Organization; 2013.</bok>

2. Sexually transmitted infections, issues in adolescent health and development. Geneva: World Health Organization; 2004. </bok>

3. Roudi-Fahimi F, Ashford L, Khalil K. Advancing research to inform reproductive health policies in the Middle East and North Africa. Washington (DC): Population Reference Bureau; 2008. </bok>

4. Mayaud P, Mabey D. Approaches to the control of sexually transmitted infections in developing countries: old problems and modern challenges. Sex Transm Infect. 2004;80:17482. $</ \mathrm{jrn}>$

5. Sexually transmitted and other reproductive tract infections: a guide to essential practice. Geneva: World Health Organization; 2005.</bok>

6. Willis J, Wilson G, Anderson I, Rosenthal D, Smith A, Fairley C, et al. An evaluation of the Tri-State HIV/STI Project 2001-2002. Canberra: Department of Health and Ageing; 2004.</other>

7. Global strategy for the prevention and control of sexually transmitted infections: 2006-2015: breaking the chain of transmission. Geneva: World Health Organization; 2007.</bok>

8. González-Calvo J, Gonzalez VM, Lorig K. Cultural diversity issues in the development of valid and reliable measures of health status. Arthritis Rheum. 1997;10:448-56.</jrn>

9. Maneesriwongul W, Dixon JK. Instrument translation process: a methods review. J Adv Nurs. 2004;48:175-86.</jrn>

10. Hedayati-Moghaddam MR, Moradi Marjaneh M, Eftekharzadeh Mashhadi I. Knowledge and attitudes of physicians in private practice towards HIV/AIDS in Mashhad, Iran. Int J STD AIDS. 2012;23:e11-6.</jrn>

11. Ghasemi S, Kabir A, Ansari Jafari M, Jalali M, Amini A, FaghihiKashani AH, et al. Psychometric properties of a standardized questionnaire of knowledge, attitude, and practice of Iranian medical specialists about viral hepatitis. Hepat Mon. 2012;12:e7650.</jrn>
12. Hoben $M$, Mahler C, Bär M, Berger S, Squires JE, Estabrooks $\mathrm{CA}$, et al. German translation of the Alberta context tool and two measures of research use: methods, challenges and lessons learned. BMC Health Serv Res. 2013;13:478.</jrn>

13. Jaworski BC, Carey MP. Development and psychometric evaluation of a self-administered questionnaire to measure knowledge of sexually transmitted diseases. AIDS Behav. 2007;11:557-74.</jrn>

14. Harkness J, Pennell BE, Schoua-Glusberg A. Survey questionnaire translation and assessment. In: Presser S, Rothgeb JM, Couper MP, Lessler JT, Martin E, Martin J, et al., editors. Methods for testing and evaluating survey questionnaires. Hoboken (NJ): John Wiley \& Sons; 2004.</edb>

15. Harkness J. Questionnaire translation. In: Harkness J, Van de Vijer F, Moher P, editors. Cross-cultural survey methods. Hoboken (NJ): John Wiley \& Sons; 2003. pp. 35-56.</edb>

16. Mear I, Giroudet C. Linguistic validation procedures. In: Acquadro C, Conway K, Giroudet C, Mear I, editors. Linguistic validation manual for health outcome assessments. 2nd ed. Lyon: MAPI Institute; 2012.</edb>

17. Frost MH, Reeve BB, Liepa AM, Stauffer JW, Hays RD. What is sufficient evidence for the reliability and validity of patient-reported outcome measures? Value Health. 2007;10 Suppl.2:S94-105.</jrn>

18. Fayers PM, Machin D. Quality of life: the assessment, analysis and interpretation of patient-reported outcomes. 2nd ed. Chichester (West Sussex): John Wiley \& Sons; 2007.</bok>

19. Tavakol M, Dennick R. Making sense of Cronbach's alpha. Int J Med Educ. 2011;2:53-5.</jrn>

20. Beaton DE, Bombardier C, Guillemin F, Ferraz MB. Guidelines for the process of cross-cultural adaptation of self-report measures. Spine. 2000;25:3186-91.</jrn>

21. Pourmarzi D, Rimaz S, Merghati Khoei EA. Sexual and reproductive health educational needs in engaged couples in Tehran in 2010. Sex Res Soc Policy. 2014;11:225-32.</jrn> 